\title{
Pemenuhan Hak-Hak Korban Pelanggaran Berat Hak Asasi Manusia Di Indonesia
}

\author{
Bonaventura Pradana Suhendarto \\ bonaven97@gmail.com \\ Mahasiswa Magister Ilmu Hukum Universitas Diponegoro \\ Jl. Imam Bardjo, SH, No. 1-3, Kampus UNDIP Pleburan, Semarang
}

\begin{abstract}
Serious violations of human rights occurred in Indonesia despite Indonesia's ratification of a number of international human rights law instruments. Victims, including their family and descendants, experiences suffering and loss. Still, there are many victims who haven't received their rights until now. International law holds states accountable for the victims' dignity as human beings. This research will examine the fulfillment of the rights of the victims in order to obtain effective and fair remedy and to analyze the application of international human rights law in Indonesia in order to fulfill the rights of the victims of serious violations of human rights. This research was conducted using a sociological juridical approach that collects and analyzes qualitative data. The result shows that the right to truth, the right to justice, the right to reparation and the guarantee of non-repetition are the forms of rights within the framework of transitional justice that must be given to the victims. These rights are interrelated, so they must be fulfilled thoroughly. Indonesia made real efforts to fulfill the rights by establishing a human rights court to resolve the cases of Timor-Timur (East Timor), Tanjung Priok and Abepura. Another effort is made by establishing legal regulations. In fact, Indonesia only recognizes and regulates some rights. The existing legal regulations have not yet encouraged effective implementation, making them difficult to implement. It is necessary to evaluate and re-conceptualize existing legal regulations so that the rights of victims are fully recognized and easy to apply.
\end{abstract}

Keywords : Human rights, victims, serious violations, reparation

ABSTRAK: Pelanggaran berat HAM terjadi di Indonesia meskipun telah meratifikasi sejumlah instrumen hukum HAM internasional. Korban termasuk keluarga dan keturunannya mengalami penderitaan dan kerugian. Hingga kini masih banyak korban yang belum menerima hak-hak mereka. Hukum internasional mengharuskan negara bertanggung jawab demi harkat martabat korban sebagai manusia. Kajian ini akan mengulas tentang pemenuhan hak-hak korban agar memperoleh pemulihan yang efektif dan berkeadilan serta menganalisa penerapan hukum HAM Internasional di Indonesia dalam upaya pemenuhan hak korban pelanggaran berat HAM. Penelitian dilakukan dengan metode pendekatan yuridis sosiologis yang mengumpulkan dan menganalisa data kualitatif. Hasil penelitian menunjukkan bahwa hak atas kebenaran (right to truth), hak atas keadilan (right to justice), hak atas reparasi (right to reparation) dan jaminan ketidak-berulangan (guarantees of non-repetition) merupakan bentuk hak-hak dalam kerangka keadilan transisi/ transitional justice yang harus diberikan pada korban. Hak-hak tersebut saling berkaitan, sehingga wajib dipenuhi seluruhnya. Upaya nyata dilakukan oleh Indonesia dengan membentuk pengadilan HAM untuk menyelesaikan kasus Timor-Timur, Tanjung Priok, dan 
Abepura. Upaya lain dilakukan dengan membentuk peraturan hukum. Faktanya, Indonesia hanya mengakui dan mengatur sebagian hak saja. Peraturan hukum yang ada pun belum mendorong pelaksanaan yang efektif sehingga sulit diterapkan. Maka, perlu mengevaluasi dan mengkonsepkan kembali peraturan hukum yang ada agar hak korban diakui seluruhnya dan mudah diterapkan.

Kata kunci : Hak-asasi-manusia, korban, pelanggaran berat, reparasi.

\section{PENDAHULUAN}

\section{LATAR BELAKANG}

Deklarasi Universal Hak Asasi Manusia (DUHAM) tahun 1948 menjadi momentum internasional terhadap penghargaan harkat dan martabat manusia. Momentum ini tidak terlepas dari sejarah panjang segala bentuk penindasan dan kekejaman dunia terhadap manusia. Perang Dunia I (1914-1918) yang menewaskan sedikitnya 30 juta orang ${ }^{1}$ dan Perang Dunia II (1939-1945) yang menewaskan sedikitnya 100 juta orang ${ }^{2}$ terlebih dahulu terjadi sebelum melatarbelakangi tonggak sejarah terwujudnya DUHAM sebagai dokumen penting internasional.

Negara Indonesia turut menjunjung tinggi harkat dan martabat manusia yang diwujudkan salah satunya melalui peraturan perundang-undangan. Unsur penghargaan harkat dan martabat manusia sejak awal telah dicantumkan dalam perumusan UndangUndang Dasar Negara Republik Indonesia (UUD NRI) Tahun 1945. Unsur tersebut menjadi lebih spesifik setelah dilakukan amandemen UUD NRI Tahun $1945 .{ }^{3}$ Tidak hanya itu, terdapat sejumlah produk hukum lain yang mengatur dan memuat mengenai HAM, termasuk membentuk Komisi Nasional Hak Asasi Manusia (Komnas HAM).

Keseriusan Indonesia dengan membentuk berbagai instrumen hukum mengenai HAM ternyata tidak membendung terjadinya pelanggaran terhadap HAM. Indonesia pun tidak luput dari sejumlah konflik yang berujung pada pelanggaran berat HAM. Kasus pelanggaran berat HAM yang pernah terjadi yaitu tragedi kemanusiaan pembantaian tahun 1965; Penembakan Misterius (1982-1985); Peristiwa Talangsari di Lampung (1989); Kasus Penghilangan Orang secara Paksa (1997-1998); Kerusuhan Mei 1998; Penembakan Trisakti, Semanggi I, dan Semanggi II (1998-1999); kasus Wasior dan Wamena di Papua (2000); kasus invasi dan jajak pendapat di Timor Leste; kasus konflik di Aceh; kasus di Abepura. ${ }^{4}$ Ada pula kasus-kasus lain yang menimpa para aktivis HAM seperti Munir.

\footnotetext{
${ }^{1}$ Arthasalina, "5 Perang Besar dengan Korban Terbanyak Sepanjang Sejarah”, 23 Desember 2018, https://www.idntimes.com/hype/fun-fact/dian-septi-arthasalina-1/5-perang-besar-dengan-korbanterbanyak-sepanjang-sejarah-clc2/full

${ }^{2}$ Ibid.

${ }^{3}$ Majda El Muhtaj, 2005, Hak Asasi Manusia dalam Konstitusi Indonesia Edisi Kedua, Jakarta: Kencana Prenada Media Group, hlm. 9.

${ }^{4}$ Kristian Erdianto, "Konflik dan Pelanggaran HAM, Catatan Kelam 20 Tahun Reformasi”, 10 November 2018, https://nasional.kompas.com/jeo/konflik-dan-pelanggaran-ham-catatan-kelam-20-tahun-reformasi.
} 
Indikasi kasus pelanggaran berat HAM dewasa ini justru cenderung berkembang dan rata-rata bermula dari konflik komunal. Salah satunya tentang kekerasan terhadap jamaah Ahmadiyah di berbagai daerah yang sampai saat ini masih terancam keberadaannya. Jamaah Ahmadiyah di berbagai daerah mengalami pengusiran dan kekerasan bahkan berujung pada kematian. Kehadiran Negara untuk melindungi tentu sudah menjadi kewajiban. Terkadang yang terjadi cenderung sebaliknya dan memilih untuk menuruti kemauan demonstran atau kehendak mayoritas dengan membubarkan kegiatan. ${ }^{5}$ Belum lagi kasus-kasus kekerasan komunal yang mengakibatkan rusaknya budaya masyarakat dan benda-benda budayanya seperti yang terjadi di Ambon, dimana kerusakan budaya dan benda-benda adat yang menjadi simbol identitas dan budaya masyarakat tersebut tidak mendapatkan perhatian sama sekali, seperti tidak ada dampaknya pada kemanusiaan secara universal. ${ }^{6}$

Sekalipun kasus-kasus pelanggaran berat HAM di Indonesia sudah lama berlalu, hilangnya ratusan ribu sampai jutaan nyawa akibat adanya serangkaian kejahatan bagi mereka yang masih hidup merupakan persoalan yang tidak boleh dilupakan. Para korban pada umumnya telah tiada (meninggal), namun penyelesaian dan keadilan bukanlah masalah masih hidup atau tidaknya seseorang. ${ }^{7}$

Apapun jenis pelanggaran berat HAM yang dilakukan terhadap para korban tentu saja menimbulkan penderitaan dan kerugian bahkan sampai saat ini. Contoh kerugian yang dialami korban mulai dari kehilangan harta dan benda, pekerjaan, potensi pendapatan, kesempatan pendidikan, biaya pengobatan. Para korban juga menderita cacat fisik dan mental karena berbagai kekerasan yang pernah ia rasakan. Penderitaan itu tidak hanya menimpa mereka yang mengalami langsung berbagai jenis pelanggaran berat HAM, tetapi juga berdampak pada keluarga dan keturunannya. Contohnya, stigmatisasi para korban Tragedi 1965 juga menimpa keluarga dan keturunannya, belum lagi seperti Ibu Sumarsih yang sampai saat ini kehilangan anaknya bernama Wawan karena menjadi korban penembakan Tragedi Semanggi I. Sudah lebih dari 20 tahun Ibu Sumarsih bersama dengan keluarga korban lainnya menuntut keadilan kepada Pemerintah dengan menggelar "Aksi Kamisan" di depan Istana Negara setiap hari kamis. ${ }^{8}$

Adanya sejumlah produk hukum seharusnya dapat dimanfaatkan oleh negara dalam upaya pertanggungjawaban terlebih dengan pemulihan dan pemenuhan hak-hak terhadap korban sebagai pihak yang mengalami kerugian dari peristiwa yang menimpa mereka. Menurut Theo Van Boven, pelanggaran berat HAM akan menimbulkan kewajiban bagi

5 Usman Hamid, "Insiden Ahmadiyah Pelanggaran HAM Berat", 30 Januari 2019, https://www.republika.co.id/berita/breaking-news/nasional/1 1/02/07/162714-insiden-ahmadiyahpelanggaran-ham-berat.

${ }^{6}$ Y.T.N. Dewi et.al.., 2020, "Preservation As Reconciliation: The Value Of Raising Awareness On Cultural Property In Post-Conflict Ambon", International Journal Of Conservation Science, Volume 11, Issue 4, September-December 2020, hlm. 1127-1134, http://ijcs.ro/public/IJCS-20-85_Dewi.pdf, 25 Januari 2021

${ }^{7}$ Manunggal Kusuma Wardaya, 2010, "Keadilan Bagi yang Berbeda Paham: Rekonsiliasi dan Keadilan Bagi Korban Tragedi 1965", Mimbar Hukum, Vol. 22 No. 1, hlm. 98.

8 Devina Halim, "Sumarsih, Aksi Kamisan, dan Cinta untuk Wawan...", 19 Juni 2019, https://nasional.kompas.com/read/2018/1 1/15/11240281/sumarsih-aksi-kamisan-dan-cinta-untuk-wawan. 
negara pelanggar untuk melakukan pemulihan bahkan para korban berhak sepenuhnya mengajukan pemulihan pada pengadilan nasional maupun pengadilan internasional. ${ }^{9}$ Pemulihan ini penting untuk memberikan keadilan bagi korban. Upaya nyata untuk pemulihan dengan pemenuhan hak-hak korban di Indonesia dinilai masih sebatas wacana saja. Upaya yang dilakukan dianggap baru sebatas koordinasi dan pembahasan antar lembaga yang tidak kunjung dilanjutkan. ${ }^{10}$

Menarik apabila melihat Afrika Selatan yang pernah melakukan pelanggaran HAM diskriminasi rasial politik apartheid. Pada masa pemerintahan Nelson Mandela, berhasil melakukan upaya penghapusan diskriminasi rasial hingga membentuk Truth and Reconciliation Commision (TRC) untuk melakukan rekonsiliasi dan pemulihan nasional serta berperan memberikan pemikiran dalam penentuan kebijakan nasional. ${ }^{11}$ Begitu pula dengan Timor Leste melakukan rekonsiliasi dan pemulihan termasuk melalui upacara adat nahe biti boot (artinya: menggelar tikar besar) terhadap korban kejahatan milisi pro-integrasi Indonesia pada masa invasi Indonesia dan jajak pendapat. ${ }^{12}$

Seperti yang telah dilakukan berbagai negara, upaya pemulihan dan pemenuhan hak-hak korban pelanggaran berat HAM menunjukkan penghargaan kembali terhadap para korban yang juga seorang manusia. Negara hadir dengan menunjukkan tanggungjawabnya. Berdasarkan prinsip tanggungjawab negara, pelanggaran berat HAM dikategorikan sebagai tindakan salah secara internasional (internationally wrongful act) dan oleh karenanya menimbulkan pertanggungjawaban internasional dari negara tersebut yaitu kewajiban untuk melakukan pemulihan. ${ }^{13}$ Berdasarkan uraian tersebut, Penulis akan menelaah lebih dalam kaitannya dengan pemenuhan hak-hak korban pelanggaran berat HAM di Indonesia. Penulisan ini tidak mengambil sebuah kasus secara spesifik untuk diteliti, sebab penulisan ini akan menganalisa dan mengkritik kerangka hukum umum secara nasional.

\section{RUMUSAN MASALAH}

a. Bagaimana bentuk hak-hak yang seharusnya diterima oleh korban pelanggaran berat HAM?

b. Bagaimana penerapan hukum HAM internasional dalam upaya pemenuhan hak-hak korban pelanggaran berat HAM di Indonesia?

\footnotetext{
9 Andrey Sujatmoko, 2016, "Hak atas Pemulihan Korban Pelanggaran Berat HAM di Indonesia dan Kaitannya dengan Prinsip Tanggungjawab Negara dalam Hukum Internasional”, Padjajaran Jurnal Ilmu Hukum, Vol. 3 No. 2, hlm. 337.

${ }^{10}$ Ibid, hlm. 334.

${ }^{11}$ Anwar Ilmar, 2017, "Penegakan Hak Asasi Manusia di Masa Transisi Demokrasi: Kasus Afrika Selatan dan Indonesia”, Global Insight Journal, Vol. 01 No. 02, hlm. 86.

${ }^{12}$ Komisi Penerimaan, Kebenaran, dan Rekonsiliasi (CAVR) di Timor Leste, 2010, Chega! Volume IV : Laporan Komisi Penerimaan, Kebenaran, dan Rekonsiliasi (CAVR) di Timor Leste, Jakarta: PT. Gramedia, hlm. 2705-2708.

${ }^{13}$ Andrey Sujatmoko, 2016, Loc.cit.
} 


\section{METODE PENELITIAN}

Metode penelitian dilakukan dengan pendekatan yuridis sosiologis dimana spesifikasi yang digunakan ialah penelitian deskripsi analisis. Pembahasan pelanggaran berat HAM dalam penulisan ini hanya mencakup hak sipil dan politik yang kasusnya terjadi sejak masa Orde Baru sampai masa reformasi di Indonesia. Data-data yang digunakan diperoleh dari wawancara terhadap dua non-governmental organization yaitu Asia Justice and Right (AJAR) dan Lembaga Studi dan Advokasi Masyarakat (ELSAM). Data juga diperoleh dari penelitian kepustakaan dengan mengambil data-data sekunder. Analisa yang digunakan yaitu analisa kualitatif, dimana data diolah dengan interpretasi sistematis, historis, dan gramatikal.

\section{PEMBAHASAN}

\section{Bentuk Hak-Hak yang Seharusnya Diterima Korban Pelanggaran Berat HAM}

Berbicara mengenai penikmatan HAM tentu tidak akan terlepas dari negara sebagai pemangku kewajiban pemenuhan HAM berdasarkan hukum HAM Internasional. Negara secara politik dan hukum mempunyai kewenangan dan kekuasaan untuk mengerahkan alatalat kenegaraannya guna memastikan hak asasi dan kebebasan dasar manusia dapat dinikmati oleh rakyat. ${ }^{14}$ George Jellinek mengemukakan kewajiban utama negara dengan teori dan konsep kewajiban positif dan negatif. Kewajiban negatif ditandai dengan hadirnya negara hanya sebatas menghargai dan menghormati hak-hak setiap orang, sehingga tidak ada intervensi langsung dari negara. Sedangkan kewajiban positif ditandai dengan adanya intervensi dari negara baik dalam tindakan-tindakan aktif atau tindakan lainnya terlebih terhadap hak ekonomi, sosial, dan budaya. ${ }^{15}$

Pada perkembangannya, konsep tersebut dianggap kurang relevan karena masih banyak orang terlanggar HAMnya. Konsep tersebut dinilai tidak mampu mengikuti perkembangan dinamika politik internasional, regional, maupun nasional. Oleh karenanya para pakar hukum internasional merumuskan ulang kewajiban negara tersebut menjadi tiga yaitu kewajiban untuk melindungi (to protect), menghormati (to respect), dan memenuhi (to fulfill) HAM secara menyeluruh. ${ }^{16}$

Kewajiban menghormati (to respect) mengharuskan negara untuk menghindari intervensi langsung terhadap hak setiap orang. Contohnya, negara tidak melakukan pembunuhan untuk menghormati hak hidup orang. kewajiban melindungi (to protect) mengharuskan negara mengambil tindakan nyata untuk mencegah terjadinya pelanggaran berat HAM. Sedangkan, kewajiban memenuhi (to fulfill) negara memiliki kewajiban mengambil tindakan legislatif, administratif, peradilan dan langkah lain yang diperlukan

\footnotetext{
${ }^{14}$ Pasal 2 ayat (1) dan (7) Piagam Persatuan Bangsa-Bangsa (PBB)

${ }^{15}$ Mulki Makmun, Hasil Wawancara Penelitian dengan Asia Justice and Rights (AJAR) yang diwakili oleh Mulki Makmun sebagai Program Officer Asia Justice and Rights (AJAR) di Kantor AJAR Jl. Tebet Utara II C, No. 22A, Tebet, Jakarta, pada tanggal 9 April 2019.

${ }^{16} \mathrm{Ibid}$; lihat juga Andrey Sujatmoko. 2015. Hukum HAM dan Hukum Humaniter. Jakarta: PT. Raja Grafindo Persada, hlm. 59.
} 
guna memastikan bahwa para pejabat negara dapat melaksanakan penghormatan dan perlindungan $\mathrm{HAM}^{17}$

Kewajiban utama tersebut telah diamanatkan oleh masyarakat internasional sehingga keberlakuannya wajib dilaksanakan. Kewajiban tersebut wajib diterapkan oleh negara termasuk ketika terdapat masyarakat yang hak-haknya dilanggar. Kewajiban negara untuk melindungi (to protect) mendapat porsi yang cukup tinggi dalam menangani korban pelanggaran berat HAM, meskipun demikian bukan berarti tidak melakukan dua kewajiban lainnya. Kewajiban ini tidak hanya berfungsi mencegah pelanggaran berat HAM, tetapi juga dilaksanakan pasca terjadinya pelanggaran berat HAM termasuk melakukan investigasi hingga penuntutan pelaku. Selain itu, kewajiban tersebut juga mengakomodasi upayaupaya pemulihan dengan memberikan hak-hak korban.

Umumnya pelanggaran berat HAM banyak terjadi pada masa pemerintahan negara yang otoriter, meski tidak menutup kemungkinan pula terjadi pada pemerintahan yang lebih bersifat demokratis. Pada konteks ini, terdapat suatu masa yang dinamakan sebagai masa transisi atau peralihan yang biasanya ditandai dengan ${ }^{18}$ :

a. Runtuhnya kepala pemerintahan rezim otoriter, namun sebagian aparatur dibawahnya masih tetap sama.

b. Lembaga legislatif, yudikatif beserta aparatur penegak hukumnya masih sama.

c. Adanya kasus-kasus pelanggaran berat HAM yang belum dipertanggungjawabkan sehingga mengemuka desakan-desakan untuk menyelesaikan semua itu baik terhadap pelaku maupun terutama korban.

d. Adanya berbagai langkah perubahan hukum dan politik guna meletakkan dasar-dasar kehidupan negara hukum dan demokrasi.

Penyelesaian kasus pelanggaran berat HAM menjadi salah satu prasyarat terbebas dari masa transisi. Isu tuntutan keadilan bagi korban pelanggaran berat HAM yang diharapkan tercapai dalam masa transisi biasanya disebut sebagai keadilan transisional (transitional justice).

Ruti G. Teitel menawarkan 5 macam bentuk keadilan dalam masa transisi yang dimaknai sebagai upaya penegakan keadilan. Bentuk-bentuk tersebut ialah keadilan pidana, keadilan historis, keadilan reparasi, keadilan administratif, dan keadilan konstitusional. ${ }^{19}$ Persatuan Bangsa-Bangsa (PBB) sendiri memaknai keadilan transisional sebagai proses dan mekanisme yang lengkap dalam mengupayakan perdamaian antara masyarakat dengan warisan pelanggaran masa lalu berskala besar guna memastikan akuntabilitas, melayani keadilan, dan mencapai rekonsiliasi. Pada akhirnya para pakar sepakat menentukan bentuk hak-hak bagi korban pelanggaran berat HAM yang didasarkan pada hukum internasional modern (hukum humaniter, hukum pidana internasional, hukum pengungsi internasional,

\footnotetext{
${ }^{17}$ Mulki Makmun, Op.cit.

${ }^{18}$ Suparman Marzuki. 2012. Pengadilan HAM di Indonesia: Melanggengkan Impunity. Jakarta: Erlangga, hlm. 18.

19 Suparman Marzuki, 2012, Op.cit, hlm. 19; lihat pula Ruti G. Teitel, 2004, Keadilan Transisional, Sebuah Tinjauan Komprehensif, Jakarta: ELSAM.
} 
dan hukum HAM internasional). ${ }^{20}$ Bentuk-bentuk tersebut dinilai mampu mencapai pemulihan efektif dan dikenal sebagai empat pilar transitional justice, antara lain sebagai berikut:

1) Hak atas kebenaran (Right to Truth)

Negara seringkali menolak menyuarakan dan mengungkap kebenaran yang sesungguhnya terjadi pada saat pelanggaran tersebut dilakukan. Hal ini menjadi salah satu penyebab terulangnya pelanggaran berat HAM. Pengungkapan kebenaran ini penting untuk mengetahui akar permasalahan dan negara maupun masyarakat akan memahami kebenaran yang sesungguhnya. ${ }^{21}$ Tak jarang narasi peristiwa atau sejarah yang terjadi seringkali dibuat berbeda untuk membenarkan segala tindakan yang dilakukan oleh negara melalui aparaturnya. Oleh karenanya para korban terstigma hingga para generasi penerus bangsa kurang memahami apa yang sesungguhnya terjadi.

Hak atas kebenaran ini senada dengan bentuk keadilan di masa transisi menurut Ruti G. Teitel yaitu keadilan historis. Menurutnya, pengungkapan kebenaran peristiwa kemanusiaan di masa rezim sebelumnya adalah keadilan yang harus diungkap dan diketahui sebagai pembelajaran agar tidak terulang kembali. Pengabaian kebenaran masa lalu atas HAM akan berdampak pada proses berpikir bagi tatanan kehidupan sosial politik suatu bangsa ke depan. ${ }^{22}$

Proses pencarian kebenaran fakta peristiwa atau sejarah dapat dilakukan melalui jalur resmi oleh pemerintah maupun tidak resmi oleh masyarakat sipil. Upaya pencarian kebenaran secara resmi dapat meliputi pembentukan Komisi Kebenaran dan Rekonsiliasi (KKR), komisi penyelidikan, investigasi oleh Komnas HAM, misi pencarian fakta, investigasi kejahatan, dan penyidikan yang diinisiasi oleh pemerintah. Proses peradilanpun selain menentukan tanggungjawab pelaku, juga menjadi upaya dalam menentukan kebenaran peristiwa yang kontroversial sebab masa transisi merupakan masa konflik antara politik dan sejarah. ${ }^{23}$ Sedangkan upaya tidak resmi sering dilakukan oleh masyarakat sebagai respon atas lambannya kinerja pemerintah. Pendokumentasian pelanggaran, laporan masyarakat umum, investigasi media, pembuatan film dokumenter, penelitian akademik, dan lainnya merupakan upaya-upaya yang sering dilakukan oleh masyarakat sipil.

2) Hak atas Keadilan (Right to Justice)

Impunitas (impunity) atau kekebalan hukum kerap kali dijumpai di berbagai negara. Tak jarang pelaku justru terlindungi atau justru masih menduduki jabatan strategis dalam pemerintahan sehingga terhindar dari jeratan hukum. Sebaliknya, para korban berusaha keras untuk terus menuntut kepada negara agar tidak melupakan peristiwa yang pernah terjadi. Para korban maupun masyarakat internasional memiliki hak atas keadilan dimana

\footnotetext{
${ }^{20}$ Guidance Note of the Secretary - General: United Nations Approach to Transitional Justice; Mulki Makmun, Op.cit.

${ }^{21}$ Mulki Makmun, Ibid.

${ }^{22}$ Suparman Marzuki, 2012, Op.cit, hlm. 20.

${ }^{23}$ Ruti G. Teitel, Op,cit., hlm 94-95.
} 
mereka yang menjadi pelaku dapat bertanggungjawab atas perbuatannya melalui proses peradilan, sehingga tidak terjadi kekebalan hukum. ${ }^{24}$

Ruti G. Teitel juga mengungkapkan bentuk yang senada yaitu keadilan pidana (legal justice) dimana hak ini lebih luas bertujuan agar para korban mendapatkan pengakuan, jaminan, perlindungan, kepastian hukum, dan perlakuan yang sama dihadapan hukum (equality before the law). ${ }^{25}$ Tuntutan untuk kasus-kasus pelanggaran berat HAM dapat dilakukan di Pengadilan Pidana Internasional (The International Criminal Court/ ICC) yang berkedudukan di Den Haag, Belanda dengan yurisdiksi mencakup kejahatan kemanusiaan, genosida, kejahatan perang, dan kejahatan agresi; Pengadilan Campuran/ Hybrid yang terdiri atas penuntut umum, penyidik, dan beberapa hakim yang berasal dari negara yang bersangkutan dan internasional; atau Pengadilan Nasional suatu negara. ${ }^{26}$

3) Hak atas Reparasi (Right to Reparation)

Negara wajib membangun hubungan kembali terhadap korban dengan menawarkan kepedulian dan memberikan tanggungjawab salah satunya dengan berbagai macam program reparasi. Reparasi sendiri menurut Jimenez de Arechaga, mantan hakim the International Court of Justice, merupakan istilah yang menggambarkan beragam cara bagi negara agar terbebas dari gugatan internasional atas kerugian karena pelanggaran kewajiban internasional. ${ }^{27}$ Reparasi ditujukan untuk penggantian segala kerugian bersifat materil maupun non-materil bagi korban. ${ }^{28}$ Adapun beberapa program reparasi dalam kerangka transitional justice menurut beberapa pakar dan hukum internasional adalah sebagai berikut:

\section{a. Restitusi (Restitution)}

Restitusi merupakan upaya-upaya memulihkan atau mengembalikan keadaan korban kembali seperti semula sebelum HAMnya terlanggar. Restitusi ini dilakukan oleh pelaku atau pihak ketiga yang bertanggungjawab. ${ }^{29}$

b. Kompensasi (Compensation)

Kompensasi merupakan penggantian kerugian terhadap setiap kerugian ekonomis korban akibat pelanggaran berat HAM. Kerugian tersebut termasuk kerugian fisik atau mental; kehilangan kesempatan seperti pendidikan, dan keuntungan lain; kerugian materil dan hilangnya pendapatan termasuk potensi pendapatan; kerusakan moral dan reputasi; serta biaya-biaya yang diperlukan untuk memperoleh bantuan hukum, medis,

\footnotetext{
${ }^{24}$ Mulki Makmun, Op.cit.

${ }^{25}$ Ibid. ;Suparman Marzuki, 2012, Op.cit, hlm. 19

${ }^{26}$ Ibid

27 Titon Slamet Kurnia, 2005, Reparasi (Reparation) terhadap Korban Pelanggaran HAM di Indonesia, Bandung: PT. Citra Aditya Bakti, hlm. 2.

${ }^{28}$ Theo Van Boven. 2001. Tentang Mereka yang Menjadi Korban: Kajian Terhadap Hak Korban atas Restitusi, Rehabilitasi, dan Kompensasi. Jakarta: ELSAM, hlm. 4.

${ }^{29}$ Principle IX number 19 Basic Principles and Guidelines on the Right to a Remedy and Reparation for Victims of Gross Violations of International Human Rights Law and Serious Violations of International Humanitarian Law; lihat pula Article 8 Declaration of Basic Principles of Justice for Victims of Crime and Abuse of Power 1985; Theo Van Boven dalam Titon Slamet Kurnia, Op.cit, hlm. 3; Mulki Makmun, Op.cit.
} 
dan obat-obatan..$^{30}$ Pemberian kompensasi dilakukan oleh negara tanpa memandang pelaku telah memberikan restitusi atau tidak.

c. Rehabilitasi (Rehabilitation)

Rehabilitasi merupakan upaya pemulihan dengan memberikan pelayanan medis, psikologis, hukum dan sosial oleh negara. ${ }^{31}$

d. Kepuasan (Satisfaction)

Kepuasan ini terdiri dari berbagai macam langkah yang dilakukan oleh negara untuk kehormatan dan moral korban, yaitu mulai dari (1) Pengukuran efektif yang ditujukan untuk penghentian pelanggaran berat HAM; (2) Pembuktian fakta secara lengkap dan pengungkapan kebenaran secara terbuka; (3) Pencarian terhadap orang yang hilang, identitas anak-anak yang diculik, orang-orang yang terbunuh, dan bantuan pemulihan, identifikasi dan penguburan kembali korban sesuai dengan permintaan keluarga atau praktik budaya keluarga; (4) Pernyataan resmi atau keputusan pengadilan yang mengembalikan martabat, reputasi, dan hak-hak hukum korban atau pihak lain yang terkait dengan korban; (5) Permintaan maaf termasuk pengakuan terhadap fakta dan penerimaan tanggungjawab; (6) Sanksi yudisial atau administratif terhadap orang yang dianggap bertanggungjawab atas pelanggaran tersebut; (7) Peringatan dan penghormatan terhadap korban; (8) Memasukkan dalam pelatihan HAM, buku-buku teks sekolah atau sejarah, pelanggaran-pelanggaran berat HAM yang dilakukan secara akurat. ${ }^{32}$

e. Reformasi yang Efektif (Effective Reforms)

Reformasi yang efektif memberikan korban dengan jaminan bahwa kekerasan dan kejahatan tidak akan terulang kembali padanya. ${ }^{33}$

4) Jaminan Ketidak-berulangan (Guarantees of non-repetition)

Bentuk hak ke-empat ini ditujukan tidak hanya pada para korban tetapi juga masyarakat umum suatu negara dengan berorientasi pada reformasi kedepan. Perubahan untuk menjamin ketidak-berulangan pelanggaran berat HAM sangat bergantung pada konteks institusi atau sistem yang perlu direformasi meliputi undang-undang, institusi pendidikan, sistem peradilan, media, aparat keamanan, dan sistem politik. Jaminan ini senada dengan keadilan administratif dan konstitusional menurut Ruti G. Teitel. Keadilan

\footnotetext{
${ }^{30}$ Principle IX number 20 Basic Principles and Guidelines on the Right to a Remedy and Reparation for Victims of Gross Violations of International Human Rights Law and Serious Violations of International Humanitarian Law; lihat pula Article 12 Declaration of Basic Principles of Justice for Victims of Crime and Abuse of Power 1985; Theo Van Boven dalam Titon Slamet Kurnia, Op.cit, hlm. 3; Mulki Makmun, Ibid.

${ }^{31}$ Principle IX number 21 Basic Principles and Guidelines on the Right to a Remedy and Reparation for Victims of Gross Violations of International Human Rights Law and Serious Violations of International Humanitarian Law; Lihat pula Theo Van Boven dalam Titon Slamet Kurnia, Op.cit, hlm. 3; Mulki Makmun, Op.cit.

${ }^{32}$ Principle IX number 22 Basic Principles and Guidelines on the Right to a Remedy and Reparation for Victims of Gross Violations of International Human Rights Law and Serious Violations of International Humanitarian Law; Lihat pula Theo Van Boven dalam Titon Slamet Kurnia, Op.cit, hlm. 3-4; Mulki Makmun, Ibid.

${ }^{33}$ Mulki Makmun, Ibid.
} 
administratif mendorong penyingkiran dari pemerintahan yang baru secara sistematis terhadap kelompok tertentu yang pernah terlibat. Sedangkan keadilan konstitusional mendorong reformasi atau pembaharuan di sektor hukum yang umumnya bertujuan menetapkan prinsip berbangsa yang demokratis serta supaya HAM diakui dan dihormati. ${ }^{34}$

Penulis sependapat dengan beberapa pakar dan hukum internasional yang menganggap ke-empat bentuk hak tersebut sebagai bentuk-bentuk hak yang wajib didapatkan oleh para korban pelanggaran berat HAM agar tercapai keadilan dan pemulihan yang efektif. Meskipun demikian, tidak dipungkiri dalam perkembangannya sulit diwujudkan karena terbentur oleh beberapa faktor. Setiap kasuspun memiliki karakter yang berbeda sehingga mempengaruhi proses penyelesaian hingga tak jarang para korban pada akhirnya hanya dominan memperjuangkan pemulihan pada salah satu atau beberapa bentuk hak dalam transitional justice.

\section{Penerapan Hukum HAM Internasional di Indonesia dalam Upaya Pemenuhan Hak Korban Pelanggaran Berat HAM}

Hingga saat ini, Indonesia masih menyimpan sejumlah kasus pelanggaran berat HAM yang belum terselesaikan termasuk yang terjadi pada saat rezim otoriter berkuasa. Berkaca pada negara lain, seperti Jerman, Afrika Selatan, Australia, dan sebagainya telah memulai bahkan sebagian besar sudah berdamai dengan sejarah kelamnya bersama korban. Seharusnya Indonesia pun dapat melakukan demikian terlebih hukum HAM internasional telah merumuskan kewajiban utama negara terkait pelanggaran berat HAM. Pasal 2 ayat (3) Kovenan Internasional Hak Sipil dan Politik menjelaskan bahwa setiap negara wajib menjamin pelaksanaan upaya pemulihan yang efektif terhadap korban baik melalui lembaga pemerintah maupun lembaga peradilan yang ada. Sebagai salah satu negara yang meratifikasi kovenan tersebut, Indonesia wajib menjamin seluruh upaya pemulihan korban dapat terwujud dengan mekanisme dan pelaksanaan yang mudah.

Upaya pemulihan korban dengan memenuhi hak-haknya dapat terbagi menjadi dua upaya yang berbeda namun saling berkaitan yaitu upaya dalam peraturan hukum dan upaya konkrit dalam pelaksanaan/ tindakan. Upaya dalam peraturan hukum dilakukan dengan pembentukan ketentuan hukum yang akan memberikan dasar upaya pelaksanaan. Sedangkan upaya konkrit dalam pelaksanaan/ tindakan merupakan upaya yang telah atau sedang dilakukan suatu negara dalam menerapkan peraturan hukum yang telah dibuat. Kedua upaya tersebut sebenarnya tengah dilakukan oleh Indonesia dalam hal pemenuhan hak korban. Upaya konkrit dalam tindakan pernah dilakukan oleh pemerintah dengan mekanisme pengadilan HAM. Mekanisme ini menjadi salah satu upaya yang dapat memberikan kepastian hukum, jaminan, pemulihan, persamaan dihadapan hukum bagi korban karena dapat mewujudkan hak atas keadilan (right to justice), hak atas kebenaran (right to truth), dan hak atas reparasi (right to reparation) secara sekaligus.

Hanya tiga kasus yang secara resmi diupayakan melalui pengadilan HAM yaitu terhadap kasus pelanggaran berat HAM Timor-Timur (Pengadilan HAM ad-hoc), kasus

\footnotetext{
${ }^{34}$ Suparman Marzuki, 2012, Op.cit, hlm. 20-21.
} 
Tanjung Priok (dibentuk pengadilan HAM ad-hoc), dan kasus Abepura (dibentuk pengadilan HAM permanen). Sebagai contoh, penulis akan mengulas secara singkat pada kasus TimorTimur dan kasus Abepura. Pada kasus Timor-Timur timbul karena adanya serangkaian peristiwa yang terjadi sebelum dan sesudah jajak pendapat di tahun 1999. Berdasarkan hasil penyelidikan Komnas HAM dan tim penyidik Kejaksaan Agung menunjukkan adanya pelaku yang bertanggungjawab atas kasus pelanggaran berat HAM Timor-Timur. Panglima Komando Daerah Militer IX/ Udayana, Mayjen Adam R. Damiri adalah salah satu yang bertanggungjawab karena dianggap memiliki komando langsung di wilayah yang meliputi Bali, Nusa Tenggara Timur, Nusa Tenggara Barat, dan Timor-Timur. ${ }^{35}$

Komisi Penyelidikan Pelanggaran (KPP) $\mathrm{HAM}^{36}$ yang dibentuk oleh Komnas HAM berhasil menunjukkan adanya unsur meluas (widespread) dan sistematis (systematic) untuk menentukan adanya pelanggaran berat HAM. Sifat meluas ditandai dengan masifnya kejahatan yang dilakukan di berbagai wilayah dan masifnya korban. Sedangkan unsur sistematis terlihat dari pola, cara, atau modus operandi kejahatan yang terjadi. ${ }^{37}$ Adam R. Damiri dianggap bertanggungjawab karena sebagai Pangdam IX/ Udayana seharusnya dapat mengendalikan atau menghentikan prajuritnya untuk tidak melakukan serangkaian kekerasan. Serangkaian tindakan yang menyebabkan pelanggaran berat HAM juga tidak mungkin tidak diketahui oleh dirinya sebagai Pangdam terlebih tindakan-tindakan baik yang dirancang maupun yang terjadi jumlahnya tidak sedikit dan berkelanjutan. ${ }^{38}$

Setelah dilakukan proses peradilan dengan Pengadilan HAM Ad-hoc Timor-Timur, Majelis Hakim berpendapat bahwa telah terjadi pelanggaran berat HAM dan menghukum Adam R. Damiri dengan sanksi pidana penjara selama 3 (tiga) tahun. Keputusan Majelis Hakim tersebut sebenarnya menuai kontroversi karena bertentangan dengan Pasal 37 dan 40 Undang-Undang Nomor 26 Tahun 2000 tentang Pengadilan HAM dimana pidana penjara 25 tahun dengan minimal 10 tahun. Terlepas dari kontroversi yang ada, setidaknya Majelis Hakim tingkat pertama ini menyatakan perbuatan tersebut terbukti dan tidak membiarkan pelaku pelanggaran berat HAM lepas dari tuntutan hukum. Akan tetapi, Adam R. Damiri mengajukan banding yang berujung pada putusan pembebasan. la dibebaskan setelah Majelis Hakim tingkat banding membatalkan hukuman sebelumnya karena menganggap pengadilan pertama salah menerapkan hukum, minimnya fakta hukum, dsb. 39

Berbeda dengan kasus Timor-Timur, pada kasus Abepura dibentuk pengadilan HAM permanen satu-satunya hingga saat ini di Indonesia. Kasus tersebut berawal dari adanya penyerangan Mapolsek Abepura pada tanggal 7 Desember tahun 2000 oleh sekelompok massa yang menyebabkan seorang petugas kepolisian meninggal dunia. Tak

${ }^{35}$ David Cohen, Fadillah Agus, dan Widati Wulandari, 2008, Pengadilan Setengah Hati: Eksaminasi Publik atas Putusan Pengadilan HAM Kasus Timor-Timur, Jakarta : ELSAM, hlm. 9.

${ }^{36}$ KPP HAM dibentuk dan diberikan fungsi penyelidikan dengan landasan hukum Undang-Undang Nomor 39 Tahun 1999 tentang Hak Asasi Manusia dan Peraturan Pemerintah Pengganti Undang-Undang (Perppu) Nomor 1 Tahun 1999 tentang Pengadilan HAM karena pada saat itu Undang-Undang Nomor 26 Tahun 2000 belum terbentuk.

${ }^{37}$ David Cohen, Fadillah Agus, dan Widati Wulandari, Op.cit, hlm. 19-26

${ }^{38} \mathrm{Ibid}$.

${ }^{39} \mathrm{Ibid}$, hlm. 84-86, 122 
lama kemudian, penyerangan kembali terjadi di Bundaran Abepura oleh sekelompok massa yang merusak dan menewaskan satpam Kantor Dinas Otonom Tk I Irian Jaya, Kotaraja bernama Markus Pradana. ${ }^{40}$

Atas dasar peristiwa tersebut, pengejaran dan penyekatan dilakukan saat itu juga oleh kepolisian setempat dibantu Brimob Polda Papua yang dikendalikan langsung oleh Kombes Pol Johny Wainal Usman sebagai Komandan Satuan (Dansat). Polisi melakukan pengejaran dan penyekatan di berbagai tempat di Abepura dan sekitarnya yang diikuti dengan penahanan di Mapolres Jayapura dan Mapolsek Abepura. Akibat dari pengejaran dan penyekatan tersebut, menyebabkan terjadinya penyiksaan, pembunuhan kilat (summary killings), penganiayaan, perampasan kemerdekaan atau kebebasan fisik secara sewenang-wenang, penangkapan dan penahanan sewenang-wenang, pelanggaran atas hak milik, dan pengungsian secara tidak sukarela. ${ }^{41}$

Laporan Penyelidikan KPP HAM Abepura menunjukkan bahwa telah terjadi pelanggaran berat HAM yang dilakukan secara sistematis (systematic) dan meluas (widespread). Laporan KPP HAM juga mendakwa Kombes Pol Johny Wainal Usman sebagai orang yang bertanggungjawab. Temuan lengkap dari KPP HAM ternyata tidak membuahkan hasil manis pada putusan Pengadilan HAM Abepura. Majelis Hakim pada akhirnya justru membebaskan Terdakwa dari hukuman dan menolak bahwa telah terjadi pelanggaran berat HAM. Salah satu alasannya ialah Majelis Hakim menganggap unsur sistematis dan meluas tidak terpenuhi, padahal secara jelas dapat dibuktikan melalui bukti-bukti yang telah ditemukan oleh KPP HAM. Putusan hakim ini dianggap berakibat pada timbulnya preseden buruk untuk keputusan pengadilan HAM yang akan datang. ${ }^{42}$

Upaya konkrit dengan menghadirkan mekanisme pengadilan yang baru dilakukan terhadap tiga kasus tersebut dianggap sebagai upaya setengah hati dengan hasil akhir yang tidak mencerminkan keadilan bagi korban. Hak atas keadilan menjadi belum terpenuhi karena pada dasarnya diwujudkan dengan adanya penghukuman pelaku, pertanggungjawaban pelaku, dan pemulihan bagi korban. Pada kasus-kasus pelanggaran berat HAM lain, prosesnya masih stagnant dan belum masuk pada ranah peradilan. Akibatnya tak jarang upaya konkrit tidak resmi dilakukan oleh para korban maupun NGO dengan pendokumentasian ingatan para korban baik melalui film, laporan, karya atau kajian akademik, dan lainnya mengingat usia para korban yang tidak muda lagi.

Pada konteks upaya peraturan hukum, Indonesia mengupayakan pemenuhan hakhak korban dengan berbagai peraturan hukum yang memberikan acuan mekanisme dan jaminan bagi korban. Ditegaskan dalam Pasal 8 Undang-Undang Nomor 39 Tahun 1999 tentang Hak Asasi Manusia bahwa negara dalam hal ini diwakili oleh pemerintah wajib dan merupakan pihak yang memberikan perlindungan, pemajuan, penegakan, serta pemenuhan HAM. Para korban pun tidak luput dari tanggungjawab pemerintah. Berikut peraturan

\footnotetext{
${ }^{40}$ Diajeng Wulan Christianty, Ifdhal Kasim, dan Trihoni Nalesti Dewi, 2007, Pengadilan Pura-Pura: Eksaminasi Publik atas Putusan Pengadilan HAM Kasus Abepura, Jakarta: ELSAM, hlm. 9.

${ }^{41}$ Ibid, hlm. 9-10.

${ }^{42}$ Ibid, hlm. 99-103.
} 
hukum di Indonesia yang mengakomodasi upaya pemenuhan bentuk hak-hak korban pelanggaran berat HAM:

1) Upaya Pemenuhan Hak atas Keadilan (Right to Justice) dalam Peraturan Hukum

Pada tahun 2000 Indonesia mengesahkan Undang-Undang Nomor 26 Tahun 2000 tentang Pengadilan HAM yang juga dilakukan atas respon masyarakat baik nasional maupun internasional. Undang-undang ini diharapkan mampu membawa pelaku pelanggaran berat HAM ke ranah hukum untuk melakukan pertanggungjawaban. Terhadap kasus-kasus pelanggaran berat HAM sebelum diundangkannya undang-undang tersebut, dapat dibentuk pengadilan HAM ad-hoc untuk mengadili para pelaku. ${ }^{43}$ Sedangkan terhadap pelanggaran berat HAM yang terjadi setelah adanya undang-undang tersebut dilakukan dengan pengadilan HAM permanen. ${ }^{44}$

Ironisnya, hingga saat ini penegakan hukum melalui pengadilan HAM sulit dilaksanakan dan baru tiga kasus saja. Dari ketiga kasus tersebut pun dianggap kurang memberikan rasa keadilan bagi korban. Beberapa kasus lain ternyata masih berhenti karena mengalami permasalahan termasuk penolakan dari Kejaksaan Agung dengan dalih bukti tidak mencukupi, meski Komnas HAM berulang kali membantah. ${ }^{45}$ Disisi lain, keharusan penyelenggaraan pengadilan HAM ad-hoc atas persetujuan Dewan Perwakilan Rakyat (DPR) dan Presiden menambah beban permasalahan terwujudnya peradilan. ${ }^{46}$ Pembentukan pengadilan HAM seharusnya tidak perlu melalui rekomendasi dari DPR, sebab terdapat unsur politis yang seringkali menghambat dan bertentangan dengan hukum yang ada. Berikut sejumlah kasus yang belum ditindaklanjuti kembali oleh Kejaksaan Agung yaitu (a) kasus Trisakti, Semanggi 1, dan Semanggi 2; (b) Kasus Wasior dan Wamena, Papua; (c) kasus pembunuhan di Talangsari; (d) Kasus Mei 1998; (e) Kasus penghilangan paksa aktivis.

Sulitnya prosedur pembentukan pengadilan dan tidak adanya kemauan politik/ political will dari pemerintah dan DPR membuat peluang untuk menghadirkan hak atas keadilan (right to justice) bagi para korban menjadi jauh dari harapan. Menurut pengalaman tiga kasus yang masuk ke ranah peradilan pun hasilnya tidak memuaskan. Padahal, dari segi hukum memberikan peluang pemenuhan hak atas keadilan (right to justice) dengan adanya Undang-Undang Pengadilan HAM.

2) Upaya Pemenuhan Hak atas Kebenaran (Right to Truth) dalam Peraturan Hukum

Upaya ini pernah dilakukan oleh Indonesia dengan adanya Undang-Undang Nomor 27 Tahun 2004 tentang Komisi Kebenaran dan Rekonsiliasi (KKR) sebagai tindak lanjut atas Ketetapan MPR Nomor V/MPR/2000 Tahun 2000. Komisi ini dibentuk untuk menggali kebenaran atas sejumlah kasus pelanggaran berat HAM yang pernah terjadi. Akan tetapi,

\footnotetext{
${ }^{43}$ Pasal 43 ayat (1) Undang-Undang Nomor 26 Tahun 2000 tentang Pengadilan Hak Asasi Manusia.

${ }^{44}$ Pasal 4 Undang-Undang Nomor 26 Tahun 2000 tentang Pengadilan Hak Asasi Manusia.

45 ICTJ \& KontraS, 2011, Keluar Jalur, Keadilan Transisi di Indonesia Setelah Jatuhnya Soeharto, Jakarta: ICTJ \& KontraS, hlm. 41; Wahyu Wagiman, Hasil Wawancara Penelitian dengan Lembaga Studi dan Advokasi Masyarakat (ELSAM) yang diwakili oleh Wahyu Wagiman sebagai Direktur Eksekutif di Kantor ELSAM J1. Siaga II No. 31 Pejaten Barat, Pasar Minggu, Jakarta, pada tanggal 9 April 2019.

${ }^{46}$ Pasal 43 ayat (2) Undang-Undang Nomor 26 Tahun 2000 tentang Pengadilan Hak Asasi Manusia.
} 
terdapat kejanggalan dalam undang-undang tersebut yang dinilai melanggar konstitusional sehingga diajukan judicial review, diantaranya:47

a. KKR berwenang untuk merekomendasikan amnesti bagi para pelaku,

b. Kasus-kasus yang telah dibawa ke KKR tidak dapat dilakukan proses hukum di pengadilan,

c. Kompensasi dapat diberikan kepada korban apabila pelaku kejahatan telah diberi amnesti.

Mahkamah Konstitusi berpendapat bahwa syarat pemberian reparasi dengan amnesti bagi pelaku jelas melanggar perlindungan HAM dalam UUD NRI Tahun 1945. Namun, Mahkamah Konstitusi justru membatalkan keseluruhan undang-undang tersebut sehingga mengakibatkan pada batalnya pembentukan KKR. Meski Mahkamah Konstitusi telah merekomendasikan untuk membuat Undang-Undang KKR yang baru, namun hingga kini belum terwujud. ${ }^{48}$

Upaya pemenuhan hak atas kebenaran terus dilakukan baik secara resmi maupun tidak resmi. Secara resmi juga dapat dilakukan melalui mekanisme pengadilan HAM. Proses peradilan HAM akan meluruskan fakta yang terjadi, sehingga dalam putusannya pun dapat menyimpulkan bahwa telah terjadi pelanggaran berat HAM. Akan tetapi, seperti yang dijelaskan pada pembahasan sebelumnya bahwa pembentukan pengadilan HAM permanen maupun ad-hoc masih sulit diwujudkan.

Upaya melalui jalur tidak resmi juga banyak dilakukan oleh berbagai Lembaga Swadaya Masyarakat (LSM). Sembari melakukan pendampingan terhadap korban, berbagai LSM menggali data dari cerita ingatan para korban yang kemudian didokumentasikan baik berbentuk film, laporan, buku, dsb. Upaya ini dilakukan untuk mengukap kebenaran dan dalam rangka mengawal pemerintah agar terus mengupayakan pemenuhan hak atas kebenaran bagi korban melalui proses yang resmi.

3) Upaya Pemenuhan Hak atas Reparasi (Right to Reparation) dalam Peraturan Hukum

Upaya ini dilakukan Indonesia dalam dua undang-undang yaitu Undang-Undang Pengadilan HAM dan Undang-Undang Nomor 13 Tahun 2006 sebagaimana diubah dengan Undang-Undang Nomor 31 Tahun 2014 tentang Lembaga Perlindungan Saksi dan Korban (LPSK). Melalui Undang-Undang Pengadilan HAM hanya mengakomodasi sebagian program reparasi yaitu restitusi, kompensasi, dan rehabilitasi. Pasal 1 dalam butir 4, 5, dan 6 Peraturan Pemerintah (PP) Nomor 3 Tahun 2002 tentang Kompensasi, Restitusi, dan Rehabilitasi Terhadap Korban Pelanggaran Hak Asasi Manusia yang Berat menyatakan :

(4) Kompensasi adalah ganti kerugian yang diberikan oleh negara karena pelaku tidak mampu memberikan ganti kerugian sepenuhnya yang menjadi tanggung jawabnya.

(5) Restitusi adalah ganti kerugian yang diberikan kepada korban atau keluarganya oleh pelaku atau pihak ketiga, dapat berupa pengembalian harta milik,

${ }^{47}$ ICTJ \& KontraS, Op.cit, hlm. 31

${ }^{48}$ Ibid. 
pembayaran ganti kerugian untuk kehilangan atau penderitaan, atau penggantian biaya untuk tindakan tertentu.

(6) Rehabilitasi adalah pemulihan pada kedudukan semula, misalnya kehormatan, nama baik, jabatan, atau hak-hak lain.

Perumusan pengertian kompensasi menimbulkan konsekuensi sulitnya para korban untuk mendapatkan kompensasi. Kompensasi mensyaratkan adanya pelaku yang bersalah dan menyatakan pelaku berkewajiban untuk membayar restitusi terlebih dahulu. Ketentuan tersebut menjadikan kompensasi tidak serta merta diberikan jika pelaku tidak dinyatakan bersalah oleh pengadilan meskipun diakui bahwa terdapat pelanggaran berat HAM. ${ }^{49}$ Lebih lanjut undang-undang tersebut menyatakan bahwa pemberian ketiga program reparasi tersebut hanya berdasarkan amar putusan pengadilan HAM permanen maupun ad-hoc..$^{50}$ Putusan pemberian reparasi akan selalu bersamaan dengan putusan terhadap pelaku pelanggaran berat HAM. Maka, adanya syarat tersebut menandakan bahwa pemberian reparasi bukanlah menjadi yang utama. Pemenuhan hak atas reparasi (right to reparation) bergantung pada ada tidaknya pelaku dan bersifat accessoir. Disyaratkan pula dalam PP tersebut, reparasi hanya diberikan ketika telah berkekuatan hukum tetap..$^{51}$

Jika sejenak mengingat pembahasan sebelumnya, dari ketiga pengadilan HAM yang pernah dibentuk hanya putusan pengadilan HAM ad-hoc kasus Tanjung Priok yang memutuskan pemberian restitusi, kompensasi, dan rehabilitasi pada korban. Namun, dalam pelaksanaannya ditemukan kendala teknis penghitungan dan terdapat penolakan eksekusi pemberian reparasi tersebut oleh Pengadilan Negeri Jakarta Pusat atas dasar dibebaskannya para pelaku ditingkat banding. ${ }^{52}$

Alternatif pemenuhan hak atas reparasi diatur dalam Undang-Undang LPSK. Sama halnya dengan Undang-Undang Pengadilan HAM, restitusi dan kompensasi yang diatur dalam Undang-Undang LPSK mensyaratkan adanya putusan pengadilan HAM terlebih dahulu. ${ }^{53}$ Perbedaannya ialah Undang-Undang LPSK memberikan mandat kepada LPSK untuk mengajukan permohonan tersebut kepada pengadilan HAM.

Apabila restitusi dan kompensasi akan diajukan oleh LPSK sebelum adanya putusan pengadilan berkekuatan hukum tetap, maka permohonan diajukan melalui Kejaksaan Agung sebagai penuntut umum untuk digabungkan dengan tuntutannya. Jika permohonan akan diajukan oleh LPSK setelah adanya putusan pengadilan berkekuatan hukum tetap, maka berdasarkan Pasal 7A ayat (5) undang-undang tersebut LPSK dapat mengajukan permohonan kepada pengadilan untuk dimintakan penetapan. Meskipun memperjelas

49 Supriyadi Widodo Eddyono \& Zainal Abidin, 2016, Memastikan Pemenuhan Hak atas Reparasi Korban Pelanggaran HAM yang Berat, Jakarta: Institute for Criminal Justice Reform, hlm. 14.

${ }^{50}$ Pasal 35 ayat (2) Undang-Undang Nomor 26 Tahun 2000 tentang Pengadilan Hak Asasi Manusia; Pasal 4 Peraturan Pemerintah Nomor 3 Tahun 2002 tentang Kompensasi, Restitusi, dan Rehabilitasi Terhadap Korban Pelanggaran Hak Asasi Manusia yang Berat.

51 Pasal 3 ayat (1) Peraturan Pemerintah Nomor 3 Tahun 2002 tentang Kompensasi, Restitusi, dan Rehabilitasi Terhadap Korban Pelanggaran Hak Asasi Manusia yang Berat.

${ }^{52}$ Wahyu Wagiman \& Zainal Abidin, Op.cit, hlm. 13.

${ }^{53}$ Pasal 7 ayat (3) Undang-Undang Nomor 13 Tahun 2006 sebagaimana diubah dengan Undang-Undang Nomor 31 Tahun 2014tentang Lembaga Perlindungan Saksi dan Korban. 
prosedur, tetapi tetap terdapat permasalahan substansi yaitu kompensasi diberikan jika pelaku tidak mampu memberi restitusi.

Disisi lain terdapat program reparasi lain yang diatur dalam undang-undang LPSK yaitu pemberian bantuan. Serupa dengan rehabilitasi, pemberian bantuan yang dimaksud menurut Pasal 6 Undang-Undang LPSK dan Pasal 34 ayat (2) PP Nomor 44 Tahun 2008 adalah berupa bantuan medis dan rehabilitasi psikososial/ psikologis. Pada penerapannya selama ini, pemberian bantuan terhadap korban tersebut lebih banyak diterapkan daripada bentuk hak lainnya. ${ }^{54}$

Dasar pemberian bantuan oleh LPSK yaitu pertama dengan putusan pengadilan HAM berkekuatan hukum tetap jika perkara telah diputus oleh pengadilan HAM. ${ }^{55}$ Kedua, dapat pula dengan surat keterangan dari Komnas HAM yang menyatakan bahwa dari hasil penyelidikan, orang tersebut merupakan korban dan dimohonkan untuk menerima reparasi..$^{56}$ Artinya program bantuan ini menjadi satu-satunya bentuk pemberian hak atas reparasi (right to reparation) terhadap korban yang tidak bergantung pada pengadilan. Pemberian bantuan ini dinilai lebih besar peluangnya untuk diberikan. ${ }^{57}$ Peluang ini mengundang antusiasme dan harapan besar para korban untuk mendapatkan salah satu haknya. Hal ini dibuktikan dengan terus meningkatnya permohonan yang diterima oleh LPSK dari tahun ke tahun. Tingginya permintaan korban pada LPSK tidak diimbangi anggaran yang ada. Anggaran yang tersedia masih terbatas dan digunakan tidak hanya bagi korban pelanggaran berat HAM saja, sehingga perlu ditingkatkan..$^{58}$

4) Upaya Pemenuhan Jaminan Ketidak-berulangan (guarantees of non-repetition) dalam Peraturan Hukum di Indonesia

Sejumlah perubahan besar atau reformasi dilalui Indonesia pasca jatuhnya rezim pemerintahan Orde Baru. Reformasi dilakukan dengan amandemen UUD NRI Tahun 1945. Perubahan paling mencolok ialah pembatasan waktu kekuasaan pemerintah negara dimana Pasal 7 mengamanatkan jabatan presiden dan wakil presiden selama 5 tahun dan dapat dipilih kembali dalam jabatan yang sama untuk satu kali masa jabatan. Ketentuan ini untuk mencegah terjadinya kekuasaan pemerintah yang tak terbatas waktu sehingga meminimalisir pula tindakan penyalahgunaan kekuasaan. ${ }^{59}$

Selain itu UUD NRI Tahun 1945 juga mencantumkan pengaturan yang lebih spesifik mengenai penghargaan HAM. Diaturnya ketentuan tersebut tidak lepas dari pengalaman berbagai peristiwa pelanggaran berat HAM yang pernah terjadi. Berbagai reformasi hukum dilakukan dengan pembentukan-pembentukan instrumen hukum nasional dalam bidang

\footnotetext{
${ }^{54}$ Wahyu Wagiman, Op.cit.

55 Pasal 35 ayat (2) huruf c Peraturan Pemerintah Nomor 44 Tahun 2008 tentang Pemberian Kompensasi, Restitusi, dan Bantuan Kepada Saksi dan Korban.

${ }^{56}$ Pasal 35 ayat (2) huruf b Peraturan Pemerintah Nomor 44 Tahun 2008 tentang Pemberian Kompensasi, Restitusi, dan Bantuan Kepada Saksi dan Korban.

${ }^{57}$ Wahyu Wagiman, Op.cit.

${ }^{58}$ Ibid.; lihat juga Betty Itha, 2017, "Sebuah Catatan: Pemberian Bantuan Bagi Korban Pelanggaran berat HAM yang Berat", dalam Nikmatul Hidajati (ed), Potret Perlindungan Saksi dan Korban, cetakan pertama, Jakarta: Lembaga Perlindungan Saksi dan Korban (LPSK), hlm. 107.; Laporan Tahunan Lembaga Perlindungan Saksi dan Korban Tahun 2017, hlm. 68

${ }^{59}$ Wahyu Wagiman, Ibid.
} 
HAM. Upayanya diwujudkan dengan meratifikasi beberapa instrumen hukum HAM internasional yang ada, kemudian membentuk Undang-Undang Nomor 39 Tahun 1999 tentang Hak Asasi Manusia dan Undang-Undang Nomor 26 Tahun 2000 tentang Pengadilan Hak Asasi Manusia. Adanya kedua undang-undang dan ratifikasi sejumlah instrumen HAM internasional membuat peraturan perundang-undangan lainnya ikut mengacu dan menghargai HAM.

Ketetapan Majelis Permusyawaratan Rakyat (MPR) Nomor V/MPR/2000 Tahun 2000 tentang Pemantapan Persatuan dan Kesatuan juga membuka jalan dalam upaya menjamin ketidak-berulangan terutama terhadap institusi. Tap MPR tersebut mengakui bahwa terdapat pelanggaran berat HAM yang terjadi. Tap MPR menyerukan reformasi di segala bidang supaya hal tersebut tidak terulang kembali dan tercipta ruang demokrasi bagi seluruh rakyat Indonesia, termasuk sesungguhnya mengamanatkan pembentukan KKR. Sampai saat ini, KKR belum juga terbentuk setelah Undang-Undang KKR dibatalkan oleh Mahkamah Konstitusi.

MPR juga secara resmi memisahkan peran Tentara Nasional Indonesia (TNI) dengan Kepolisian Republik Indonesia (POLRI) melalui Tap MPR Nomor VI Tahun 2000. TNI berperan dalam pertahanan negara sedangkan POLRI berperan memelihara keamanan. ${ }^{60}$ Selain itu, baik TNI maupun POLRI harus bersikap netral dalam kehidupan politik dan dilarang untuk terlibat dalam politik praktis. ${ }^{61}$ Perubahan signifikan terhadap institusi TNI dan POLRI ini dinilai sangat baik terlebih untuk membatasi kedua institusi tersebut dalam pemerintahan.

Reformasi TNI dan POLRI juga diikuti dengan institusi-institusi lain dengan penghormatan terhadap HAM. Oleh karena itu, baik TNI, POLRI, maupun institusi-institusi lain mulai mengenalkan HAM dengan mengadakan pelatihan yang berkelanjutan mengenai HAM dan membuat standar operasional prosedur (SOP) untuk meminimalisisr pelanggaran. ${ }^{62}$

Hal lain yang tidak kalah penting adalah jaminan dalam mendorong pelaksanaan yang efektif atas perubahan regulasi. Efektivitas pelaksanaan inilah yang masih belum diterapkan dengan baik di Indonesia. Masih terdapat indikasi pelanggaran berat HAM yang terjadi dan untuk penyelesaian kasus pelanggaran berat HAM masa lalu pun masih stagnant. Tentu reformasi regulasi jika tidak dibarengi oleh pelaksanaan yang baik, ketidak-berulangan atas pelanggaran berat HAM pun tidak dapat terjamin. ${ }^{63}$

Apa yang tercantum dalam berbagai peraturan hukum, tampaknya belum memenuhi keseluruhan hak-hak korban pelanggaran berat HAM. Jika yang tercantum dalam hukum tersebut diberikan kepada korban pun, tentu belum akan tercapai pemulihan yang efektif terhadap korban. Hanya hak atas keadilan (right to justice) dan sebagian hak atas reparasi

60 Pasal 2 Ketetapan Majelis Permusyawaratan Rakyat Nomor VI/MPR/2000 Tahun 2000 tentang Pemisahan Tentara Nasional Indonesia dan Kepolisian Republik Indonesia.

${ }^{61}$ Pasal 5 ayat (2) dan Pasal 10 Ketetapan Majelis Permusyawaratan Rakyat Nomor VII/MPR/2000

Tahun 2000 tentang Peran Tentara Nasional Indonesia dan Kepolisian Republik Indonesia.

${ }^{62}$ Wahyu Wagiman, Op.cit.

${ }^{63}$ Ibid. 
(right to reparation) saja yang diakui dan diatur. Untuk jaminan ketidak-berulangan (guarantees of non-repetition) sebagian telah dilakukan dengan memberikan jaminan regulasi dan belum terpenuhi secara maksimal dalam menjamin pelaksanaan yang efektif.

\section{PENUTUP}

\section{KESIMPULAN}

Setiap negara memiliki kewajiban mutlak untuk melindungi (to protect), menghormati (to respect), dan memenuhi (to fulfill) Hak Asasi Manusia terhadap masyarakatnya termasuk ketika telah terjadi pelanggaran berat HAM. Pemenuhan hak-hak korban terangkai dalam kerangka keadilan transisi (transitional justice), yang mengandung proses atau upaya perdamaian dengan warisan pelanggaran masa lalu. Bentuk hak-hak korban yang harus dipenuhi disebut sebagai empat pilar transitional justice, yaitu: (a) Hak atas kebenaran (right to truth); (b) Hak atas keadilan (right to justice); (c) Hak atas reparasi (right to reparation) yang terdiri atas kompensasi, restitusi, rehabilitasi, kepuasan (satisfaction), dan reformasi yang efektif (effective reforms); dan (d) Jaminan ketidak-berulangan (guarantees of nonrepetition). Ke-empat bentuk hak tersebut harus dipenuhi oleh negara agar tercapai pemulihan yang efektif bagi korban.

Penerapan hukum HAM internasional mengenai tanggungjawab negara dalam pemenuhan hak-hak korban di Indonesia dilakukan dengan upaya pembentukan peraturan hukum dan upaya konkrit dalam pelaksanaan/ tindakan. Upaya konkrit dalam pelaksanaan dilakukan terhadap penyelesaian kasus pelanggaran berat HAM yang terjadi di Timor-Timur, Tanjung Priok, dan Abepura melalui pengadilan HAM. Sedangkan upaya pembentukan peraturan hukum beberapa telah dilakukan, namun masih belum mendorong pelaksanaan yang efektif. Pengaturan tersebut diantaranya:

a. Hak atas Keadilan (right to justice)

Undang-Undang Pengadilan HAM mengakomodasi pemenuhan hak atas keadilan bagi korban meskipun belum memberikan pelaksanaan yang efektif. Sejak undang-undang tersebut dibentuk, hanya 2 pengadilan HAM ad-hoc dan 1 pengadilan HAM permanen yang dibentuk. Sulitnya prosedur pembentukan pengadilan dan tidak adanya political will dari Pemerintah (eksekutif) dan DPR (legislatif) membuat pengadilan HAM sulit terwujud.

b. Hak atas Kebenaran (right to truth)

Upaya pemenuhan hak atas kebenaran bagi korban dilakukan dengan mekanisme resmi maupun tidak resmi. Secara resmi dilakukan dengan membentuk UndangUndang Komisi Kebenaran dan Rekonsiliasi (KKR), tetapi oleh Mahkamah Konstitusi dibatalkan akibat bertentangan dengan UUD 1945 dan prinsip perlindungan HAM. Disisi lain, diupayakan melalui pengadilan HAM karena dianggap dapat menyelesaikan kontroversi kebenaran peristiwa yang terjadi sebelum memutuskan pertanggungjawaban pelaku. Upaya tidak resmi dilakukan oleh berbagai Lembaga Swadaya Masyarakat (LSM) atas respon lambatnya upaya resmi oleh pemerintah. 
c. Hak atas Reparasi (right to reparation)

Pemenuhan hak atas reparasi terakomodasi dalam Undang-Undang Pengadilan HAM dan Undang-Undang Lembaga Perlindungan Saksi dan Korban (LPSK). Kedua undangundang hanya mengakui program kompensasi, restitusi, dan rehabilitasi/ bantuan. Dasar pemberian reparasi adalah dengan putusan pengadilan HAM yang telah berkekuatan hukum tetap. Hak ini bersifat accessoir karena bergantung pada ada tidaknya pelaku yang dihukum. Terhambatnya pemenuhan hak atas reparasi disebabkan karena prosedur yang rumit; pengertian kompensasi yang hanya diberikan ketika pelaku tidak mampu memberikan restitusi; tidak adanya pengaturan cara penghitungan jumlah restitusi dan kompensasi; pembentukan pengadilan HAM yang masih sulit; dan adanya upaya hukum lanjutan yang memakan waktu lama. UndangUndang LPSK juga memberikan mekanisme lain pemenuhan hak atas reparasi yaitu untuk program bantuan (medis, rehabilitasi psikologis dan psikososial) tanpa adanya pelaku yang telah dihukum terlebih dahulu. Meskipun begitu, dalam perkembangannya memerlukan penguatan untuk mendorong pelaksanaan yang efektif seperti penambahan anggaran, memaksimalkan bantuan, dll.

d. Jaminan Ketidak-berulangan (guarantees of non-repetition)

Jaminan ini diberikan dengan jaminan reformasi hukum dan institusi pasca runtuhnya Orde Baru. Reformasi hukum dilakukan dengan meratifikasi instrumen hukum HAM internasional, amandemen UUD NRI Tahun 1945, pembentukan Undang-Undang HAM, dan Undang-Undang Pengadilan HAM. Reformasi institusi dilakukan dengan pembatasan waktu kekuasaan pemerintah, pemisahan TNI dan POLRI, melakukan pelatihan-pelatihan HAM, dan pembuatan SOP. Meskipun sebagian telah diatur, namun jaminan pelaksanaan yang efektif perlu dikembangkan agar menjamin ketidakberulangan suatu pelanggaran berat HAM.

Tampak bahwa peraturan hukum di Indonesia masih belum cukup mengatur dan mengakomodasi keseluruhan bentuk hak-hak yang harus diberikan pada korban pelanggaran berat HAM. Sebagian yang diatur pun belum bisa memberikan dan mendorong pelaksanaan yang efektif, terbukti dengan sulitnya pemenuhan beberapa hak yang diakui.

\section{SARAN \& REKOMENDASI}

Berdasarkan hasil kajian dan pembahasan di atas, penulis bermaksud mengusulkan dan merekomendasikan untuk mengevaluasi dan mengkonsep kembali peraturan hukum yang ada dengan penelitian mendalam dan diskusi agar hak-hak korban pelanggaran berat HAM yang diatur atau diakui di Indonesia sesuai dengan apa yang seharusnya diberikan pada korban dalam kerangka transitional justice dan dapat mendorong pelaksanaan yang efektif. 


\section{DAFTAR PUSTAKA}

\section{Buku}

Boven, Theo Van. 2001. Tentang Mereka yang Menjadi Korban: Kajian Terhadap Hak Korban atas Restitusi, Rehabilitasi, dan Kompensasi. Jakarta: ELSAM.

Christianty, Diajeng Wulan, Ifdhal Kasim, dan Trihoni Nalesti Dewi. 2007. Pengadilan PuraPura: Eksaminasi Publik atas Putusan Pengadilan HAM Kasus Abepura. Jakarta: ELSAM.

Cohen, David, Fadillah Agus, Widati Wulandari. 2008. Pengadilan Setengah Hati: Eksaminasi Publik atas Putusan Pengadilan HAM Kasus Timor-Timur. Jakarta : ELSAM.

Eddyono, Supriyadi Widodo \& Zainal Abidin. 2016. Memastikan Pemenuhan Hak atas Reparasi Korban Pelanggaran HAM yang Berat. Jakarta: Institute for Criminal Justice Reform.

ICTJ \& KontraS. 2011. Keluar Jalur, Keadilan Transisi di Indonesia Setelah Jatuhnya Soeharto. Jakarta: ICTJ \& KontraS.

Itha, Betty. 2017. "Sebuah Catatan: Pemberian Bantuan Bagi Korban Pelanggaran berat HAM yang Berat". dalam Nikmatul Hidajati (ed), Potret Perlindungan Saksi dan Korban. cetakan pertama. Jakarta: Lembaga Perlindungan Saksi dan Korban (LPSK).

Komisi Penerimaan, Kebenaran, dan Rekonsiliasi (CAVR) di Timor Leste. 2010. Chega! Volume IV : Laporan Komisi Penerimaan, Kebenaran, dan Rekonsiliasi (CAVR) di Timor Leste. Jakarta: PT. Gramedia.

Kurnia, Titon Slamet. 2005. Reparasi (Reparation) terhadap Korban Pelanggaran HAM di Indonesia. Bandung: PT. Citra Aditya Bakti.

Laporan Tahunan Lembaga Perlindungan Saksi dan Korban Tahun 2017

Marzuki, Suparman. 2012. Pengadilan HAM di Indonesia: Melanggengkan Impunity. Jakarta: Erlangga.

Muhtaj, Majda El. 2005. Hak Asasi Manusia dalam Konstitusi Indonesia Edisi Kedua. Jakarta: Kencana Prenada Media Group.

Sujatmoko, Andrey. 2015. Hukum HAM dan Hukum Humaniter. Jakarta: PT. Raja Grafindo Persada.

Teitel, Ruti G. 2004. Keadilan Transisional, Sebuah Tinjauan Komprehensif. Jakarta: ELSAM.

Jurnal

Ilmar, Anwar. 2017. "Penegakan Hak Asasi Manusia di Masa Transisi Demokrasi: Kasus Afrika Selatan dan Indonesia". Global Insight Journal. Vol. 01 No. 02.

Sujatmoko, Andrey. 2016. "Hak atas Pemulihan Korban Pelanggaran Berat HAM di Indonesia dan Kaitannya dengan Prinsip Tanggungjawab Negara dalam Hukum Internasional”. Padjajaran Jurnal Ilmu Hukum. Vol. 3 No. 2.

Wardaya, Manunggal Kusuma. 2010. "Keadilan Bagi yang Berbeda Paham: Rekonsiliasi dan Keadilan Bagi Korban Tragedi 1965”. Mimbar Hukum. Vol. 22 No. 1. 


\section{Instrumen Hukum}

Piagam Persatuan Bangsa-Bangsa

Basic Principles and Guidelines on the Right to a Remedy and Reparation for Victims of Gross

Violations of International Human Rights Law and Serious Violations of International Humanitarian Law.

Declaration of Basic Principles of Justice for Victims of Crime and Abuse of Power 1985.

International Convenant on Civil and Political Rights.

Guidance Note of the Secretary - General: United Nations Approach to Transitional Justice.

Undang-Undang Dasar Negara Republik Indonesia Tahun 1945.

Ketetapan Majelis Permusyawaratan Rakyat Nomor VI/MPR/2000 Tahun 2000 tentang

Pemisahan Tentara Nasional Indonesia dan Kepolisian Republik Indonesia.

Ketetapan Majelis Permusyawaratan Rakyat Nomor VII/MPR/2000 Tahun 2000 tentang

Peran Tentara Nasional Indonesia dan Kepolisian Republik Indonesia.

Undang-Undang Nomor 39 Tahun 1999 tentang Hak Asasi Manusia.

Undang-Undang Nomor 26 Tahun 2000 tentang Pengadilan Hak Asasi Manusia.

Undang-Undang Nomor 13 Tahun 2006 sebagaimana diubah dengan Undang-Undang Nomor 31 Tahun 2014tentang Lembaga Perlindungan Saksi dan Korban.

Peraturan Pemerintah Nomor 3 Tahun 2002 tentang Kompensasi, Restitusi, dan Rehabilitasi Terhadap Korban Pelanggaran Hak Asasi Manusia yang Berat.

Peraturan Pemerintah Nomor 44 Tahun 2008 tentang Pemberian Kompensasi, Restitusi, dan Bantuan Kepada Saksi dan Korban.

\section{Artikel}

Arthasalina, "5 Perang Besar dengan Korban Terbanyak Sepanjang Sejarah”, 23 Desember 2018,https://www.idntimes.com/hype/fun-fact/dian-septi-arthasalina-1/5-perang-besardengan-korban-terbanyak-sepanjang-sejarah-c1c2/full

Erdianto, Kristian. "Konflik dan Pelanggaran HAM, Catatan Kelam 20 Tahun Reformasi”. 10 November 2018. https://nasional.kompas.com/jeo/konflik-dan-pelanggaran-hamcatatan-kelam-20-tahun-reformasi.

Halim, Devina. "Sumarsih, Aksi Kamisan, dan Cinta untuk Wawan...". 19 Juni 2019. https://nasional.kompas.com/read/2018/11/15/11240281/sumarsih-aksi-kamisan-dancinta-untuk-wawan.

Hamid, Usman. "Insiden Ahmadiyah Pelanggaran HAM Berat". 30 Januari 2019. https://www.republika.co.id/berita/breaking-news/nasional/11/02/07/162714-insidenahmadiyah-pelanggaran-ham-berat.

Y.T.N. Dewi et.al.., 2020, "Preservation As Reconciliation: The Value Of Raising Awareness On Cultural Property In Post-Conflict Ambon", International Journal Of Conservation Science, Volume 11, Issue 4, September-December 2020, hlm. 1127-1134, http://ijcs.ro/public/IJCS-20-85_Dewi.pdf, 25 Januari 2021 


\section{Lain-lain}

Mulki Makmun. Hasil Wawancara Penelitian dengan Asia Justice and Rights (AJAR) yang diwakili oleh Mulki Makmun sebagai Program Officer Asia Justice and Rights (AJAR) di Kantor AJAR Jl. Tebet Utara II C, No. 22A, Tebet, Jakarta, pada tanggal 9 April 2019.

Wahyu Wagiman. Hasil Wawancara Penelitian dengan Lembaga Studi dan Advokasi Masyarakat (ELSAM) yang diwakili oleh Wahyu Wagiman sebagai Direktur Eksekutif di Kantor ELSAM Jl. Siaga II No. 31 Pejaten Barat, Pasar Minggu, Jakarta, pada tanggal 9 April 2019. 